Eur. J. Clin. Chem. Clin. Biochem.

Vol. 31, 1993, pp. $811-814$

(C) 1993 Walter de Gruyter \& Co. Berlin - New York

\title{
Alkaline Phosphatase in Human Semen: An Investigation Using Enzyme Inhibitors and Gel Electrophoresis
}

\author{
By L. M. Lewin ${ }^{1}$, Rachel Golan ${ }^{1}$, Yigal Soffer ${ }^{2}$, Sarita Kaufman ${ }^{2}$, Y. Yulzary ${ }^{3}$ and J. Zaidman ${ }^{3}$ \\ ${ }^{1}$ Dept. of Chemical Pathology, Sackler Medical School, Tel Aviv University \\ 2 Dept. of Obstetrics and Gynecology \\ 3 Dept. of Biochemical Pathology, Assaf HaRofe Medical Center, Tsrifin, Israel
}

(Received March 9/July 20, 1993)

Summary: Human seminal alkaline phosphatase was investigated with respect to its electrophoretic mobility, heat lability, and susceptibility to inhibition by phenylalanine, tartrate, and homoarginine. Total alkaline phosphatase activity in 30 samples of human semen was measured colorimetrically, using $p$-nitrophenylphosphate as substrate. Using linear regression analysis, no significant correlation was found between the enzyme activity and the sperm count, sperm motility, semen volume, and the concentrations of seminal inositol and fructose. The alkaline phosphatase activity was higher in the earlier portion of split ejaculate samples. Sodium $D L$-tartrate $(42 \mathrm{mmol} / \mathrm{l})$, which inhibits acid phosphatase, did not inhibit seminal alkaline phosphatase significantly. $L$-Homoarginine (10 mmol/l), an inhibitor of the liver and bone isoenzymes, inhibited the seminal enzyme $(53 \%)$, whereas $L$-phenylalanine $(12 \mathrm{mmol} / \mathrm{l})$, a strong inhibitor of placental alkaline phosphate, decraased activity by about $10 \%$. Electrophoresis of semen samples on agarose revealed a braod band which was not sharpened after treatment with neuraminidase. Semen total alkaline phosphatase was essentially totally inactivated by heating at $56^{\circ} \mathrm{C}$ for $15 \mathrm{~min}$ or $10 \mathrm{~min}$ at $65^{\circ} \mathrm{C}$; similar behaviour has been reported for the liver and bone isoenzymes. Electrophoresis after heating did not reveal a residual band of heat-stable placental-like alkaline phosphatase. Semen alkaline phosphatase appears to contain more than one isoenzyme, but placental-like alkaline phosphatase cannot be more than a minor component.

\section{Introduction}

Alkaline phosphatase ${ }^{1}$ ), EC 3.1.3.1, an enzyme which catalyses hydrolysis of organic phosphate at basic $\mathrm{pH}$ values, has been reported in the semen of man and animals $(1-6)$. It is secreted into seminal fluid by the epididymis in rabbit and dog $(5,6)$ and by the prostate and testis in man $(1,3)$. Molecular biology techniques suggest that all the alkaline phosphatase isoenzymes of the body are coded by three genes (7), whose products are the placental-, intestinal-, and osteohepatic-type alkaline phosphatase isoenzymes. After the polypeptide chains have been synthesized, sugars may

1) Enzyme

Alkaline phosphatase EC 3.1.3.1 be added to form glycoproteins, and differences in the sugar chains may affect various properties, such as electrophoretic behaviour.

The present investigation was concerned with the distribution of alkaline phosphatase activity in split ejaculates of human semen, the response of this alkaline phosphatase to the inhibitors phenylalanine, tartrate, and homoarginine, its inhibition by heat, and its behaviour in agarose gel electrophoresis.

\section{Materials and Methods}

Semen samples were obtained by masturbation after three days of sexual abstinence. Seminal volumc, cell count and motility were determined by standard methods (8). Semen fructose and 
inositol were separated by paper chromatography and detected with $\mathrm{AgNO}_{3}$ as previously described (9).

Alkaline phosphatase was determined colorimetrically, using $p$ nitrophenylphosphate as substrate $(10,11)$.

Semen samples $(5 \mu \mathrm{l})$ were submitted to electrophoresis at $\mathrm{pH}$ 8.6-9.0 on agarose for 30 minutes at 250 Volts, using the Helena Laboratories kit, with 5-bromo-4-chloro-3-indolyl phosphate as substrate and nitroblue tetrazolium chromogen to visualize the enzyme activity (12).

Heat inactivation to destroy non-placental enzymes was preformed at $56^{\circ} \mathrm{C}$ for 15 minutes, or $65^{\circ} \mathrm{C}$ for 10 minutes (15). Neuraminidase (Vibrio cholerae; Helena Laboratories kit as above) treatment was applied at $25^{\circ} \mathrm{C}$ for 15 minutes.

\section{Results and Discussion}

Assay of alkaline phosphatase activity in five sets of split ejaculate samples obtained from a male infertility clinic showed a broad range of values (tab. 1). In each patient the alkaline phosphatase concentration was higher in the earlier portion of the semen. This fraction generally contains predominantly prostatic fluid mixed with some seminal vesicle secretion and the bulk of the sperm cells and associated secretions from the testis and epididymis, whereas the later portion generally contains the bulk of the seminal vesicle secretion together with some prostatic fluid and a lower concentration of sperm cells (13).

Using linear regression analysis, no significant correlation was found between the alkaline phosphatase activity of 30 samples of semen and the sperm concentration, \% motility, semen volume, or the concentrations of either inositol (a prostatic marker) or of fructose (of seminal vesicle origin) (tab. 2). These results are consistent with the hypothesis that the alkaline phosphatase of human semen might be a mixture of several isoenzymes from different sources, and several techniques were used to distinguish between these forms.

Electrophoresis on agarose gel has been used to separate serum alkaline phosphatase isoenzymes of liver, bone, intestinal and placental origin (12). As revealed by this technique, human semen contained broad, overlapping bands of alkaline phosphatase activity, but the distribution was not identical with that normally found in blood serum (fig. 1). The electrophoretic zone was not sharpened by the use of neuraminidase, which is known to aid in separating the bands produced by the bone and liver isoenzymes (14). Heating, which destroys non-placental enzymes while leaving placental and placental-like enzymes essentially unaffected (15), inactivated the seminal alkaline phosphatase activity (tab. 3). Electrophoresis of the heated semen did not reveal a band characteristic of heatstable placental-like alkaline phosphatase under the conditions used. This indicates that the concentration of placental-like alkaline phosphatase, reported to be present in human semen (1), is too low to be measured in this way.

The isoenzymes of alkaline phosphatase have been reported to have different sensitivities to inhibitors. $L$-Phenylalanine $(12 \mathrm{mmol} / \mathrm{l})$ is an effective inhibitor of the placental-like alkaline phosphatase isoenzyme (16). It decreased seminal alkaline phosphatase activity by about $10 \%$. L-Homoarginine ( $10 \mathrm{mmol} / \mathrm{l})$, reported to inhibit the liver and bone isoenzyme (16), inhibited the semen enzyme by $53 \%$. These results, and those of heat inactivation (tab. 3), suggest that the bulk of the seminal alkaline phosphatase was of the liver enzyme type rather than the placental-like form.

Tab. 1. Some semen quantities measured in samples of human split ejaculate samples. Patients were requested to collect early and late portions in separate plastic containers, labelled I and II, respectively.

\begin{tabular}{|c|c|c|c|c|c|c|c|}
\hline & Sample No. & $\begin{array}{l}\text { Vol } \\
(\mathrm{ml})\end{array}$ & $\begin{array}{l}\text { Cells } \\
\left(10^{9} / 1\right)\end{array}$ & $\begin{array}{l}\text { Motility } \\
(\%)\end{array}$ & Inositol* & Fructose** & $\begin{array}{l}\text { Alkaline } \\
\text { phosphatase } \\
(\mathrm{U} / \mathrm{l})\end{array}$ \\
\hline A & $\begin{array}{l}\text { Split I } \\
\text { Split II }\end{array}$ & $\begin{array}{l}0.7 \\
0.8\end{array}$ & $\begin{array}{l}1.1 \\
0.2\end{array}$ & $\begin{array}{r}10 \\
0\end{array}$ & $\begin{array}{l}2 \mathrm{~N} \\
2 \mathrm{~N}\end{array}$ & $\begin{array}{l}2 \mathrm{~N} \\
2 \mathrm{~N}\end{array}$ & $\begin{array}{r}100 \\
20\end{array}$ \\
\hline B & $\begin{array}{l}\text { Split I } \\
\text { Split II }\end{array}$ & $\begin{array}{l}0.5 \\
1.0\end{array}$ & $\begin{array}{l}35 \\
11\end{array}$ & $\begin{array}{l}22 \\
50\end{array}$ & $\begin{array}{l}2 \mathrm{~N} \\
2 \mathrm{~N}\end{array}$ & $\begin{array}{r}\mathrm{N} \\
2 \mathrm{~N}\end{array}$ & $\begin{array}{l}950 \\
500\end{array}$ \\
\hline $\mathrm{C}$ & $\begin{array}{l}\text { Split I } \\
\text { Split II }\end{array}$ & $\begin{array}{l}0.5 \\
0.4\end{array}$ & $\begin{array}{l}43 \\
11\end{array}$ & $\begin{array}{l}10 \\
18\end{array}$ & $\begin{array}{l}2 \mathrm{~N} \\
2 \mathrm{~N}\end{array}$ & $\begin{array}{r}\mathrm{N} \\
2 \mathrm{~N}\end{array}$ & $\begin{array}{l}730 \\
360\end{array}$ \\
\hline D & $\begin{array}{l}\text { Split I } \\
\text { Split II }\end{array}$ & - & - & - & $\begin{array}{l}2 \mathrm{~N} \\
2 \mathrm{~N}\end{array}$ & $\begin{array}{l}2 \mathrm{~N} \\
2 \mathrm{~N}\end{array}$ & $\begin{array}{l}630 \\
281\end{array}$ \\
\hline $\mathrm{E}$ & $\begin{array}{l}\text { Split I } \\
\text { Split II }\end{array}$ & - & - & - & $\begin{array}{r}2 \mathrm{~N} \\
\mathrm{~N}\end{array}$ & $\begin{array}{r}\mathrm{N} \\
2 \mathrm{~N}\end{array}$ & $\begin{array}{l}342 \\
138\end{array}$ \\
\hline
\end{tabular}




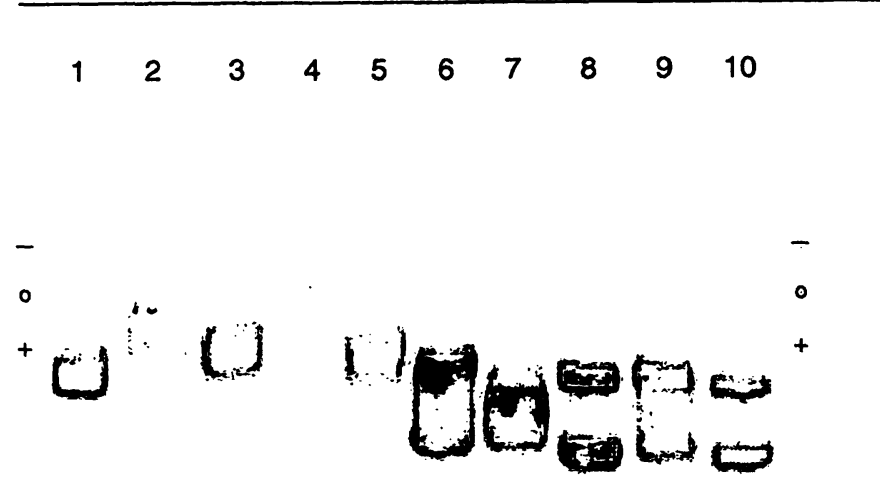

Fig. 1. Agarose gel electrophoresis of human semen and blood serum samples. Electrophoresis was performed as described in Materials and Methods, using the Helena procedure (12). The origin is marked "o". Samples $1-10$ are:

1 Semen \# 1 containing $536 \mathrm{U} / 1$ alkaline phosphatase;

2 Semen \#2 after neuraminidase treatment;

3 Semen \#3 after neuraminidase treatment;

4 Semen \#2, $332 \mathrm{U} / \mathrm{l}$ alkaline phosphatase;

5 Semen \# 3, $462 \mathrm{U} / 1$ alkaline phosphatase;

6 Blood serum with fast liver, bone and liver isozymes;

7 Blood serum with bone isozyme;

8 Blood scrum with fast liver and liver isozymes;

9 Blood serum with fast liver, bone (trace) and liver isozymes;

10 Blood serum with fast liver and liver isoenzymes.
The amount of alkaline phosphatase in semen from various species differs widely. In the bull, boar and rabbit semen, there is more alkaline phosphatase than acid phosphatase (3). In man the opposite is the case. It has even been suggested that the alkaline phosphatase activity of human semen reflects the residual activity of prostatic acid phosphatase at the elevated $\mathrm{pH}$ of the assay (3). In order to test this hypothesis we added an inhibitor of prostatic acid phosphatase, sodium $D L$-tartrate $(42 \mathrm{mmol} / \mathrm{l})$, and observed no inhibition of the alkaline phosphatase activity of the semen samples (tab. 3).

It has been reported that the alkaline phosphatase of dog and rabbit semen originates mainly from the epididymis $(5,6)$, whereas Chamberlin et al. (17) found that alkaline phosphatase in man is from the prostate secretion. Lewis-Jones et al. (1) used a specific ELISA assay to quantitate a placental-like alkaline phosphatase isoenzyme in human semen and showed that it is not present in semen from vasectomized man.

The results of the present experiments, together with the work of McLaughlin (18), suggest that there may

Tab. 2. Some semen quantities measured in samples of human semen.

Inositol and fructose were estimated semiquantitatively by paper chromatography, vs. standards (inositol: $\mathrm{N}=50 \mathrm{mg} / \mathrm{l}$; $2 \mathrm{~N}=100 \mathrm{mg} / \mathrm{l} ; \mathrm{N} / 2=25 \mathrm{mg} / \mathrm{l}$ and fructose standard solutions: $\mathrm{N}=200 \mathrm{mg} / \mathrm{l} ; 2 \mathrm{~N}=400 \mathrm{mg} / \mathrm{l} ; \mathrm{N} / 2=100 \mathrm{mg} / \mathrm{l})$.

\begin{tabular}{|c|c|c|c|c|c|c|}
\hline Sample No. & $\begin{array}{l}\text { Vol } \\
(\mathrm{ml})\end{array}$ & $\begin{array}{l}\text { Cells } \\
\left(10^{9} / 1\right)\end{array}$ & $\begin{array}{l}\text { Motility } \\
(\%)\end{array}$ & Inositol & Fructose & $\begin{array}{l}\text { Alkaline } \\
\text { phosphatase } \\
(\mathrm{U} / \mathrm{l})\end{array}$ \\
\hline 1 & 2 & 28 & 18 & $N$ & $N / 2$ & 72 \\
\hline 2 & 2.5 & 60 & 30 & $2 \mathrm{~N}$ & $N$ & 96 \\
\hline 3 & 7 & 1.9 & 25 & $2 \mathrm{~N}$ & $2 \mathrm{~N}$ & 96 \\
\hline 4 & & 0 & 0 & & & 120 \\
\hline 5 & 2.5 & 17 & 40 & & & 120 \\
\hline 6 & 5.5 & 9 & 22 & & & 126 \\
\hline 7 & 6.5 & 92 & 30 & & & 138 \\
\hline 8 & 2.5 & 105 & 42 & & & 144 \\
\hline 9 & 3.5 & 33 & 15 & $2 \mathrm{~N}$ & $2 \mathrm{~N}$ & 162 \\
\hline 10 & 2.5 & 59 & 25 & $\mathrm{~N}$ & $\mathrm{~N}$ & 167 \\
\hline 11 & 6 & 3.1 & 3 & & & 168 \\
\hline 12 & 4 & 0 & 0 & $\mathrm{~N}$ & $2 \mathrm{~N}$ & 171 \\
\hline 13 & 1 & 108 & 30 & $2 \mathrm{~N}$ & $\mathrm{~N}$ & 204 \\
\hline 14 & 1 & 2.5 & 36 & $\mathrm{~N}$ & $2 \mathrm{~N}$ & 234 \\
\hline 15 & 3.5 & 1.7 & 30 & & & 246 \\
\hline 161 & 7 & 29 & 5 & & & 252 \\
\hline 71 & 3 & 88 & 45 & $N$ & $2 \mathrm{~N}$ & 396 \\
\hline 81 & 2 & 23 & 8 & $2 \mathrm{~N}$ & $2 \mathrm{~N}$ & 432 \\
\hline 9 & 3.5 & 83 & 48 & $2 \mathrm{~N}$ & $2 \mathrm{~N}$ & 456 \\
\hline 20 & 3 & 82 & 40 & $2 \mathrm{~N}$ & $2 \mathrm{~N}$ & 486 \\
\hline 21 & 4 & 15 & 35 & $\mathbf{N}$ & $2 \mathrm{~N}$ & 527 \\
\hline 22 & 0.8 & 21 & 38 & $2 \mathrm{~N}$ & $\mathrm{~N} / 2$ & 540 \\
\hline 23 & 4 & 0 & 0 & & & 612 \\
\hline 24 & 1.7 & 31 & 11 & $2 \mathrm{~N}$ & $2 \mathrm{~N}$ & 613 \\
\hline 25 & 2 & 11 & 25 & $\mathrm{~N}$ & $\mathrm{~N}$ & 840 \\
\hline 26 & 2.5 & 65 & 40 & $2 \mathrm{~N}$ & $N / 2$ & 1066 \\
\hline 27 & 2.5 & 5.8 & 14 & $2 \mathrm{~N}$ & $\mathrm{~N}$ & 1110 \\
\hline 28 & 2.5 & 18.5 & 15 & $2 \mathrm{~N}$ & $\mathrm{~N}$ & 1230 \\
\hline 29 & 3 & 20 & 25 & $2 \mathrm{~N}$ & $\mathrm{~N} / 2$ & 1699 \\
\hline 30 & 2.5 & 56 & 34 & & & 1986 \\
\hline
\end{tabular}


Tab. 3. Inhibitory effects of heat treatment and chemical inhibitors on the alkaline phosphatase activity of human semen samples.

\begin{tabular}{lll}
\hline $\begin{array}{l}\text { Concentration } \\
(\mathrm{mmol} / \mathrm{l})\end{array}$ & $\begin{array}{l}\text { Inhibition } \\
(\%)\end{array}$ \\
\hline
\end{tabular}

\section{Experiment 1}

L-Phenylalanine

$L$-Homoarginine

$D L$-Tartrate

Heat treatment

$\begin{array}{lr}12 & 9 \\ 10 & 52 \\ 21 & 2 \\ 65^{\circ} \mathrm{C} 10 \mathrm{~min} & 100\end{array}$

Experiment 2

$L$-Phenylalanine

$L$-Homoarginine

Heat treatment

$\begin{array}{ll}12 & 13 \\ 10 & 53 \\ 56^{\circ} \mathrm{C} 15 \mathrm{~min} & 98\end{array}$

Experiment 3

DL-Tartrate

21 be more than one source of alkaline phosphatase in human semen. Singer et al. (2) have reported that there is negligible alkaline phosphatase activity in human sperm cells. They did not find a significant correlation between the total alkaline phosphatase activity of semen and the sperm count.

In the present study, heat-treatment, the use of $L$ phenylalanine and $L$-homoarginine inhibitors, and gel electrophoresis, did not separate the seminal isoenzymes well enough to allow their differential assay. In order to use alkaline phosphatase isoenzymes as markers for studying the function of their secretory organs, it will apparently be necessary to utilize assays, such as the ELISA method of McLaughlin (18), based upon the use of a monoclonal antibody specific to the one isoenzyme which is to be measured.

\section{References : :}

1. Lewis-Jones, D. I., Johnson, P. M., Desmond, A. D. \& McLaughlin, P. J. (1992) Germ cell alkaline phosphatase in human seminal plasma following vasectomy. Br. J. Urol. $69,418-420$.

2. Singer, R., Barnet, M., Allalouf, D., Schwartzman, S., Sagiv, M., Landau, B., Segenreich, E. \& Servadio, C. (1980) Some properties of acid and alkaline phosphatase in seminal fluid and isolated sperm. Arch. Androl. 5, 195-199.

3. Kavanagh, J. P. \& Bardsley, W. G. (1979) The identity of the acid and alkaline phosphatases of human seminal plasma. J. Reprod. Fert. 57, 43-48.

4. Iyer, S. K., Daron, H. H. \& Aull, J. L. (1988) Purification and properties of alkaline phosphatase from boar seminal plasma. J. Reprod. Fert. 82, 657-664.

5. Frenette, G., Dube, J. Y. \& Tremblay, R. R. (1986) Origin of alkaline phosphatase of canine seminal plasma. Arch. Androl. 16, 235-241.

6. Muller, B. (1983) Genital tract proteins in the male rabbit: II. alkaline phosphatase enzyme action and site of synthesis. Andrologia 15, 676-681.

7. Seargeant, L. E. \& Stinson, R. A. (1979) Evidence that three structural genes code for human alkaline phosphatase. Nature 281, 152-154.

8. W. H.O. (1987) WHO laboratory manual for the examination of human semen and semen-cervical mucus interaction. Cambridge University Press, Cambridge, U. K.

9. Lewin, L. M., Beer, R. \& Lunenfeld, B. (1977) Paper chromatographic estimation of fructose and myo-inositol in human semen: A method for evaluating seminal vesicle and prostatic secretion. Int. J. Fertil. 22, 48-51.

10. Anonymous (1971) Phosphatase. Sigma Technical Bulletin No. $104,6-7$.
11. Anonymous (1972) Alkaline phosphatase. Z. Klin. Chem. Klin. Biochem. 10, 182.

12. Anonymous (1989) Titan gel alkaline phosphatase isoenzyme procedure (catalogue No. 3055). Helena Laboratories, Gateshead, UK.

13. Lewin, L. M. (1977) Biochemical markers in human seminal plasma as a means of evaluating the functioning of the male reproductive tract. In: The Testis in Normal and Infertile Men: Morphology, Physiology, and Pathology (Troen, P. \& Nankin, H., eds.) pp. 505-511, Raven Press, NY.

14. Moss, D. W. \& Edwards, R. K. (1984) Improved electrophoretic resolution of bone and liver alkaline phosphatase resulting from partial digestion with neuraminidase. Clin. Chim. Acta $143 ; 172-182$.

15. O'Carroll, D., Statland, B. E., Steele, B. W. \& Burke, D. M. (1975) Chemical inhibition method for alkaline phosphatase isozymes in human serum. Am. J. Clin. Pathol. 63, $564-572$.

16. Moss, D. W. (1982) Alkaline phosphatase isozymes. Clin. Chem. 28, 2007-2016.

17. Chamberlin, L., Trusso, V. \& Sufrin, G. (1985) Alkaline phosphatase, an androgen-regulated prostatic secretory enzyme. Surg. Forum 36, 625-626.

18. McLaughlin, P. J., Lewis-Jones, I., Hutchinson, G. E. \& Johnson, P. M. (1986) Placental-type alkaline phosphatase in human seminal plasma from fertile and infertile men. Fertil. Steril. 46, 934-937.

Dr. Rachel Golan
The Dept. of Chemical Pathology
Sackler Medical School
Tel Aviv University
69978 Ramat Aviv
Israel

